\title{
Loss of Consciousness
}

National Cancer Institute

\section{Source}

National Cancer Institute. Loss of Consciousness. NCI Thesaurus. Code C50635.

An inability to purposefully respond to stimuli. 